\title{
ARROBO, Augmented Reality-Based Mobile Application for Supporting Innovative Learning in Robotics
}

\author{
https://doi.org/10.3991/ijim.v13i11.10816 \\ Abdur Rachman Yusuf, Agus Efendi $\left.{ }^{\bowtie}\right)$, Rosihan Ari Yuana \\ Universitas Sebelas Maret, Jawa Tengah, Indonesia \\ agusefendilstaff.uns.ac.id
}

\begin{abstract}
The results of the study show that the use of technology in the classroom has a positive impact on students learning and behavior. The use of technology in education also makes students more independent in learning. One form of technology is augmented reality. Augmented reality is a technology to produce and combine virtual objects into the real world. In learning robotics, there are several problems, namely limited costs and the limited number of tools. Obstacles to learning robotics in addition to the cost and number of tools, namely the limited time and condition of the class that must be arranged so that it is not chaotic. In this study, will be discussed on the development of an augmented reality mobile application named ARROBO. The purpose of making ARROBO is to overcome the problem of limited costs and the limited number of tools. In addition to discussions about development, this paper will also be presented on the results of the feasibility test of the learning media. Based on the results of the feasibility test using ISO 25010, the results obtained in the functional suitability aspect obtained a score of $100 \%$, the portability aspect obtained a score of $100 \%$, media expert ratings obtained a score of $90 \%$, and usability aspects obtained a score of $84 \%$. In addition, the assessment of material experts obtained $100 \%$ results on aspects of material accuracy. Based on these results it can be concluded that the ARROBO application belongs to the "Very Worthy" category to use.
\end{abstract}

Keywords-Augmented reality, mobile applications, technology, learning media, robotics

\section{Introduction}

In recent years, augmented reality technology is growing along with the growth in the number of smartphone and internet users in the world. Data from the Ministry of Communication and Information (KOMINFO), of Indonesia's population of 250 million people, smartphone users in Indonesia in 2015 reached more than 100 million people. With such a large number, Indonesia in fourth ranks active smartphone users after China, India, and America[1]. In the last decade, mobile device users who use the Android operating system are increasing. Increased mobile device users provide opportunities for the use of mobile devices for educational purposes[2]. Teaching and learning activities that utilize learning media with renewable technology are the right 
solution for delivering learning material. One form of use of mobile devices for educational purposes is augmented reality technology. Augmented reality itself is a technology that enables the integration of the digital world into the real world. Virtual objects appear according to environmental conditions in the real world[3]. According to Rohmah, augmented reality is a technology to produce and combine virtual objects into the real world[4].

The results showed that the use of technology in the classroom had a positive impact on students perspective on student learning and behavior. Using technology in education tends to make students more independent in learning[5]. Augmented reality makes the process of visualization and delivery of information more varied where information can be presented using digital media, one of which is a 3-dimensional object[6]. According to Qumillaila, the ability to present virtual objects by augmented reality in real life in real time can activate a sense of existence, closeness, and interaction with students[7]. Augmented reality is also considered to have an effect to increase student motivation [8]. Augmented reality can also help individuals improve their knowledge and understanding of what happens around them[9].

Researchers have reviewed the conditions in the field that there are obstacles in learning robotics in Informatics and Computer Education Department, Universitas Sebelas Maret, namely limited costs and the limited number of tools. According to Alimisis, the obstacles of learning robotics in addition to the cost and number of tools, namely the limited time and conditions of the class that must be arranged so that it is not chaotic[10]. Augmented reality can replace the function of teaching aids, often learning aids cannot be used optimally because of limited costs and the limited number of tools. From these observations, the researchers felt the need for a media to support the delivery of robotics material.

Therefore, it is necessary to conduct research that can provide innovation in learning activities, research will be carried out in Informatics and Computer Education Department, Universitas Sebelas Maret.

\section{$2 \quad$ Method}

To develop the application, the ADDIE[11] development model was chosen in this research because it has a systematic and sequential process. The ADDIE process includes analysis, design, develop, implement, and evaluate, but the researcher limits it to the develop stage. The analysis phase aims to find out the problem and the right solution to overcome the problem, in addition to the collection of teaching material and analysis of the need to create media. The material contained in this media refers to line follower robotics material, which includes components used to make line follower robots and also component installation simulations. At the design stage, material planning and display are carried out. The material is arranged based on the material taught in the class, starting from the introduction of components to assembly. The design of the display includes the front cover of the module book, module content, and user interface design. At the development stage, learning media applications are made using the waterfall model according to the design. After the 
application is completed, the application is tested for the accuracy of the material by material experts instruments adopt from Hanafi [12], then quality tested based on ISO 25010 covers functional suitability, portability, and usability [13], selected 3 points because it adjusts to the system contained in this application[14]. Functional compatibility and portability are tested by media experts. Functional compatibility aspects were tested using Test Case from softwaretestinghelp.com and portability aspects were tested using tools from the web of kobiton.com. Criteria for scoring media experts using the Guttman scale. After being tested by media experts and getting input, usability was tested on users adopting Lund's "USE Questionnaire" questionnaire[15] with 4 test points, namely usefulness, ease of use, ease of learning, and satisfaction. Scoring criteria by users using a Likert scale[16]. For the feasibility category, the application uses the assessment criteria by Riduwan [16].

\section{$3 \quad$ Result}

ARROBO is expected to be able to load all teaching material on "line follower" robotics, there are 3-dimensional illustrations on the introduction of robotics components, there is 3-dimensional animation on the installation of components, there is an information menu in which there are instructions, about applications, and application objectives. ARROBO application is designed using use case diagrams as in Figure 3.1, activity diagrams, and sequence diagrams. Use case diagrams are used to find out the role of users in this media, for example, users can choose the material to be displayed [17]. In the system, there is only one actor, namely the user. Users can access the augmented reality mode ("start" menu), which the camera will appear, users can scan on the "marker" that has been made to display simulations or 3dimensional models, the 3-dimensional model contained in the augmented reality menu can be enlarged or reduced in size with "pinch" on the screen, besides the 3dimensional model can also rotate by itself. "Marker" in augmented reality mode is a marker which consists of reference points to make it easier for the camera to read images to be recognized by the application. In the material menu, users can access material that has been compiled and adapted to teaching material, in this menu users can choose which material to display. On the about menu, there is information about the application, the purpose of the application, and how to use the application. On the exit menu, users can exit the application.

Activity diagrams describe the flow of activity in the system that is being designed, showing flow from beginning to end[18]. The activity diagram is shown in Figure 3.2. 


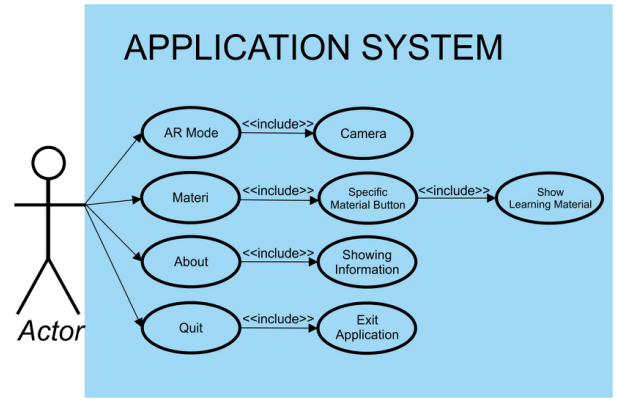

Fig. 1. Use case diagram

In the activity diagram, explained the order of use of the application, starting from splash screen then enter the main menu which is divided into 4 parts, namely "start" menu, "materi" menu, "about" menu, and "quit" menu. In the "start" menu (augmented reality mode), the user can point the camera to the "marker" or enter the material menu using the material buttons in the start menu. If a "marker" is detected, a 3-dimensional object or 3-dimensional animation will appear, if the "marker" is removed from the camera, the 3-dimensional object is lost.

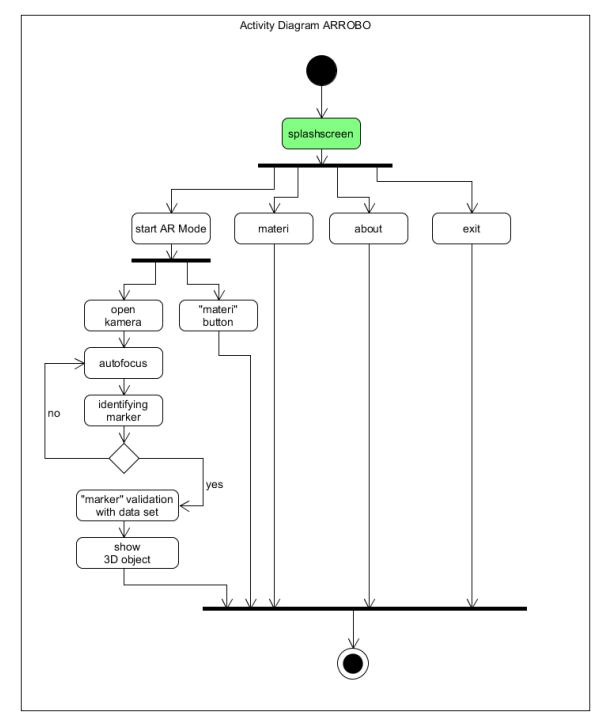

Fig. 2. Activity diagram

Sequence diagrams show interaction scenarios or steps taken in response to an event to produce a specific output. Sequence diagrams are descriptions of use case diagrams. 


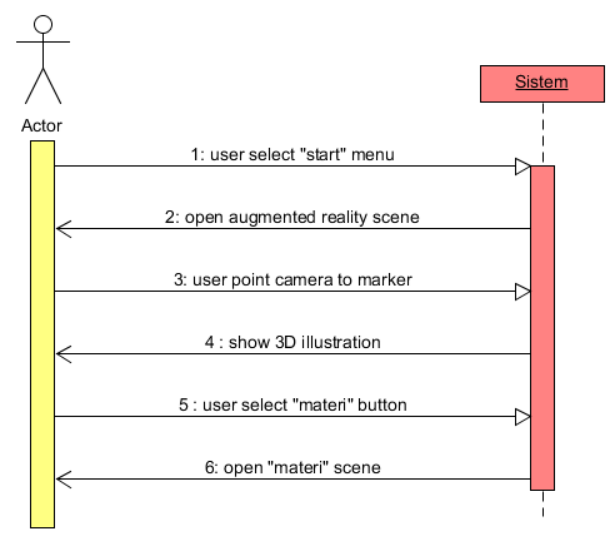

Fig. 3. Sequence diagram "start" menu

In the "start" menu sequence diagram (Figure 3.3), the initial stage is when the user selects the "start" button, then from the reciprocal sending system to display augmented reality pages and open the camera, after the camera is open, the user can point the camera at the marker in the module book, when the marker detected then a 3-dimensional animation or animation will appear. On the augmented reality page there is also a button that directs to the material page, can be accessed when the user presses the "materi" button then the material page opens.

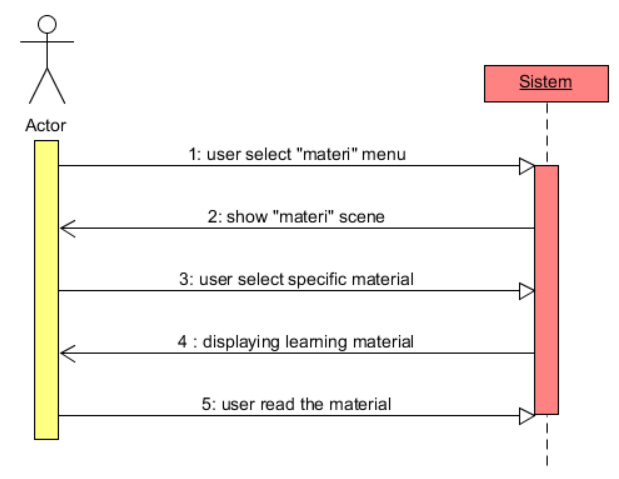

Fig. 4. Sequence diagram "materi" menu

In the "materi" menu diagram (Figure 3.4), the user selects the "materi" button, then the application opens the material page, on the material page before the user selects the material to be displayed, there is a $3 \mathrm{D}$ animation of a PCB and its components, then the user can select the material to be displayed, material appears on the screen as chosen by the user. 


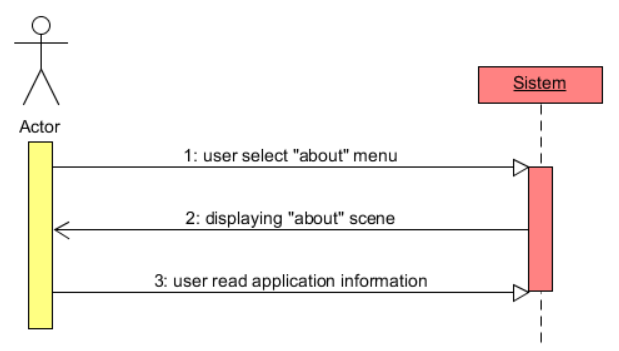

Fig. 5. Sequence diagram "about" menu

The "about" menu sequence diagram (Figure 3.5) can be accessed when the user selects the "about" button, then the system will display the application information page in the form of application objectives, about the developer, and how to use the application.

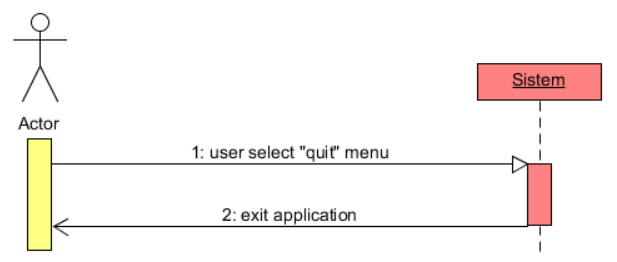

Fig. 6. Sequence diagram "quit" menu

The sequence diagram "quit" menu (Figure 3.6) works when the user selects the "quit" button, the application will exit.

ARROBO is made using some software, including Blender 2.79 used as software for making 3-dimensional objects, CorelDRAW X7 is used for making "markers", Unity is used as a game engine to create applications, Vuforia SDK as an add-on augmented reality, and Android SDK is used to compile the application from Unity into an extension file (.apk). 


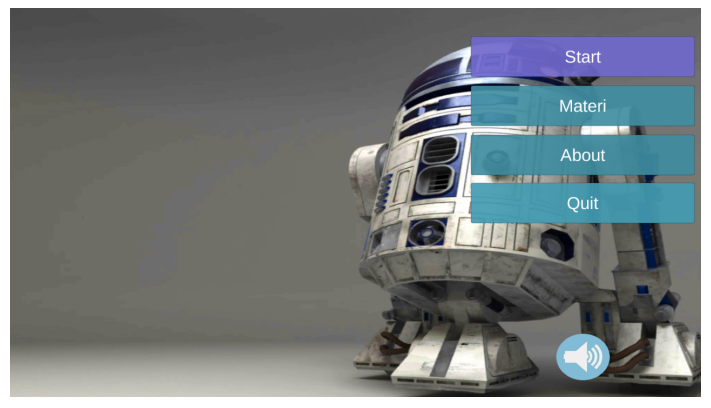

Fig. 7. App display design

In the application display design, buttons are arranged as in Figure 3.7, the display is made with landscape orientation so that when augmented reality runs, animation or 3-dimensional illustrations are not truncated as in Figure 3.8. In addition, when entering the material, the left part contains an explanation of the component and the right side contains buttons that point to a particular material.

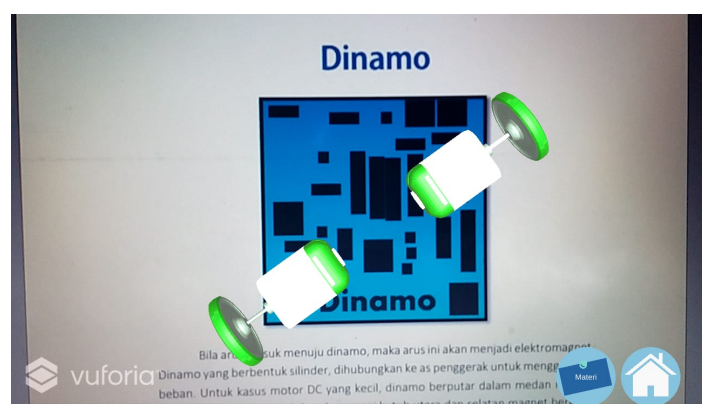

Fig. 8. Augmented reality layout

\section{Discussion}

After ARROBO was created, it was then tested by material experts, media experts, and users. On the assessment of material experts, testing was carried out through an instrument consisting of 24 questions and obtained $100 \%$ results. $100 \%$ results are obtained from the test score and the expected score. This shows, in terms of material accuracy, ARROBO fully matching with teaching material.

Furthermore, testing by media experts includes 2 aspects, namely aspects of functional suitability and portability. Functional suitability testing obtained 100\% results with 24 test points, portability testing obtained results as in Table 4.1. 
Table 1. Table 4.1 Test results at various screen resolutions and OS versions

\begin{tabular}{|c|l|l|c|c|c|c|c|}
\hline No & $\begin{array}{c}\text { Manu- } \\
\text { facture }\end{array}$ & \multicolumn{1}{|c|}{ Device name } & $\begin{array}{c}\text { OS } \\
\text { Version }\end{array}$ & $\begin{array}{c}\text { Screen } \\
\text { resolution }\end{array}$ & Install & Execute & Update \\
\hline & Samsung & Galaxy J7 Prime & 6.0 .1 & $1080 \times 1920$ & $\sqrt{ }$ & $\sqrt{ }$ & $\sqrt{ }$ \\
\hline & Motorola & Moto G (3rd Gen) & 6 & $720 \times 1280$ & $\sqrt{ }$ & $\sqrt{ }$ & $\sqrt{ }$ \\
\hline Lenovo & Yoga Tab3 Plus & 6.0 .1 & $1600 \times 2560$ & $\sqrt{ }$ & $\sqrt{ }$ & $\sqrt{ }$ \\
\hline & Samsung & Galaxy S8+ & 8.0 .0 & $1080 \times 2220$ & $\sqrt{ }$ & $\sqrt{ }$ & $\sqrt{ }$ \\
\hline & Motorola & Moto G Plus (5th Gen) & 7 & $1080 \times 1920$ & $\sqrt{ }$ & $\sqrt{ }$ & $\sqrt{ }$ \\
\hline & Sony & Xperia XZ Premium & 8.0 .0 & $1080 \times 1920$ & $\sqrt{ }$ & $\sqrt{ }$ & $\sqrt{ }$ \\
\hline & Samsung & Galaxy S9 & 8.0 .0 & $1440 \times 2960$ & $\sqrt{ }$ & $\sqrt{ }$ & $\sqrt{ }$ \\
\hline & LGE & 6.0 .1 & $1080 \times 1920$ & $\sqrt{ }$ & $\sqrt{ }$ & $\sqrt{ }$ \\
\hline & Nexus 5 & 7 & $1080 \times 1920$ & $\sqrt{ }$ & $\sqrt{ }$ & $\sqrt{ }$ \\
\hline
\end{tabular}

In the portability test, the results show that the application can run on a variety of devices because the application is relatively lightweight which does not require a lot of resources and the application can adjust the screen size of the device. But researchers have not tested the Android OS version below 6.0 (Android Marshmallow) because the tools that are used already don't carry the old Android version. Based on the results of testing functional accuracy and portability, media experts assess the appropriateness of the application. The results of media expert scoring, the application gets a score with a total percentage of $90 \%$.

After being tested by experts and get comments and critics, the next step is testing by the user. User testing includes usefulness points, ease of use, ease of learning, and satisfaction. Tests are conducted on students who are or have taken robotics courses and obtain $84 \%$ usefulness results, $85 \%$ ease of use, $90 \%$ ease of learning, and $79 \%$ satisfaction. The final percentage of testing by users gets $84 \%$. Based on Riduwan's eligibility criteria [16], the application belongs to the "Very Worthy" category.

The highest point of testing by the user is on ease of learning because the way to use the application is so easy that even new users can immediately understand how to use it. The lowest point of testing by users is in the satisfaction section because some users feel dissatisfied with the appearance and composition of the application color. The colors in the application use dark backgrounds and buttons with bright colors. But some users don't like dark colors and suggest using bright colors.

In addition, although the usefulness section gets $84 \%$ points but there is a statement that gets the lowest score from all statements, namely in statements relating to the ease of the user in solving the problem of learning robotics because according to the user, there is no variation in the robotics material outside the learning material. But the highest score is also found in the usefulness section of the statement relating to the usefulness of understanding robotics material because the material contained already includes all learning material.

ARROBO has been criticized by users, including UI improvements, which are improvements to text alignment, color combinations that are too dark to be replaced with bright colors, less detailed textures, repairs to several components that have high poly resulting in lag, and additional material beyond the material being taught. 


\section{Conclusion}

Based on the results of the research and discussion it can be concluded that the ARROBO has been created which can help students understand the robotics components with the help of 3-dimensional model illustrations. This is supported by the results of usability testing to users, namely usefulness of $84 \%$, ease of use of $85 \%$, ease of learning of $90 \%$, and satisfaction of $79 \%$. The results of the ARROBO application quality analysis obtained the results of material testing in accordance with the material taught, the results of functional suitability were very feasible, and portability was also very good. The results of the application feasibility test are conducted on users with usability test results of $84 \%$. Thus the ARROBO is declared feasible as a learning media. With the comments and critics from ARROBO users, it is expected that further research can be developed so that it includes enrichment material outside of the main material, improving the appearance, and if possible given a quiz menu.

\section{References}

[1] Kominfo, Indonesia Raksasa Teknologi Digital Asia. Diperoleh 03 Maret 2018 dari https://www.kominfo.go.id/content/detail/6095/indonesia-raksasa-teknologi-digitalasia/0/sorotan_media, 2015. https://doi.org/10.7454/jki.v4i1.8877

[2] N. Azmi, D. Maryono, and R. A. Yuana, "Development of an Android-based Learning Media Application for Visually Impaired Students," Indones. J. Informatics Educ., vol. 1, no. 1, pp. 61-68, 2017. https://doi.org/10.20961/ijie.v1i1.11796

[3] M. Akçayır and G. Akçayır, "Advantages and challenges associated with augmented reality for education: A systematic review of the literature," Educ. Res. Rev., vol. 20, pp. 1-11, 2017. https://doi.org/10.1016/j.edurev.2016.11.002

[4] N. H. Rohmah, Y. Sujana, and R. A. Yuana, "Ar-Kio: Augmented Reality-Based Application as Instructional Media on the Material of the Input and Output Device Component,” Indones. J. Informatics Educ., vol. 1, no. 2, pp. 57-64, 2017. https://doi.org/ 10.20961/ijie.v1i2.12472

[5] R. Isnaini, R. A. Yuana, and D. Maryono, "Designing Android Reward System Application in Education to Improve Learning Quality," Int. Conf. Inf. Tech., Comput. Electr. Eng., pp. 9-14, 2017. https://doi.org/10.1109/icitacee.2017.8257666

[6] A. Pramono, "Media Pendukung Pembelajaran Rumah Adat Indonesia menggunakan Augmented Reality," J. ELTEK, vol. 11, no. April, pp. 122-130, 2013.

[7] Qumillaila, B. H. Susanti, and Zulfiani, "Pengembangan Augmented Reality Versi Android sebagai Media Pembelajaran Sistem Ekskresi Manusia," Cakrawala Pendidik., vol. 1, pp. 57-69, 2017. https://doi.org/10.21831/cp.v36i1.9786

[8] J. Miguel, I. Ruiz-rube, and J. Manuel, "Augmented reality mobile app development for all R,” Comput. Electr. Eng., vol. 0, pp. 1-11, 2017.

[9] S. C. Yuen and E. Johnson, "Augmented Reality: An Overview and Five Directions for AR in Education,” J. Educ. Technol. Dev. Exch., vol. 4, pp. 119-140, 2011.

[10] D. Alimisis, "Educational robotics: Open questions and new challenges," Themes Sci. Technol. Educ., vol. 6, no. 1, pp. 63-71, 2013. 
[11] S. Kurt, ADDIE Model : Instructional Design. Diperoleh 09 Maret 2018 dari https://edu cationaltechnology.net/the-addie-model-instructional-design/, 2017.

[12] M. R. Hanafi, "Analisis dan Perancangan Aplikasi Geometra, Media Pembelajaran Geometri Mata Pelajaran Matematika Berbasis Android menggunakan Teknologi Augmented Reality," Yogyakarta, 2015.

[13] ISO25010, "The ISO/IEC 25000 series of standards," 2011. [Online]. Available: https://iso25000.com/index.php/en/iso-25000-standards. [Accessed: 15-May-2018].

[14] R. Kartono and A. Mulwinda, "Aplikasi Panduan Sosialisasi Keselamatan Lalu Lintas 'Road Safety' Menggunakan Phonegap dengan Android,” Pros. SINTAK, pp. 169-175, 2017.

[15] A. M. Lund, USE Questionnaire. Diperoleh 20 Agustus 2018 dari http://garyperlman.com/ quest/quest.cgi?form=USE, 2001.

[16] Riduwan, Dasar-dasar Statistika. Bandung: PT. Alfabeta, 2013.

[17] A. R. Pratama, Belajar Unified Modeling Language (UML) - Pengenalan. Diperoleh 09 Sep 2018 dari https://www.codepolitan.com/unified-modeling-language-uml, 2016. https:// doi.org/10.1007/springerreference 63075

[18] W. Romi Satria, Pengantar Unified Modeling Languange. Diperoleh 27 September 2018 dari https://ilmukomputer.com, 2003.

\section{Authors}

Abdur Rahman Yusuf is a researcher at Informatics Education Department, Universitas Sebelas Maret, Indonesia. His research field is mobile application development for learning, augmented reality, and also robotics. abdurrachmany@gmail.com

Agus Efendi is a lecturer at Informatics Education Department, Universitas Sebelas Maret, Indonesia. He teaches technology in education, electronics and instrumentation. Several studies that have been published in journals and conferences focus on the field of education, and robotics. agusefendi@staff.uns.ac.id

Rosihan Ari Yuana is an Indonesian computer scientist, and programming educator at Informatics Education Department, Universitas Sebelas Maret, Indonesia. He has conducted many research publications, especially in the fields of computing, computer assisted learning, and also intelligent tutoring system. He works also as a programming and mathematics book writer at several publishers. rosihanari@staff.uns.ac.id

Article submitted 2019-05-07. Resubmitted 2019-07-30. Final acceptance 2019-08-05. Final version published as submitted by the authors. 